\title{
Trade Policy towards the NICs - Options for the EEC
}

\author{
Vincent Cable
}

\section{Introduction}

It is only about five years since the 'newly industrialising countries' (NICs) became widely identified as a distinct focus of attention, both in trade policy and as a category of developing countries of interest in itself [OECD 1979; FCO 1979].' A large amount of literature on the subject is starting to pile up on the shelves. What one might call the orthodox mainstream has adopted a 'mutual interests' approach, arguing that the rapid growth of manufactured exports by the NICs is on balance modest but positive in its impact both on competing advanced industrial countries (AICs) and on the NICs themselves [OECD 1979; Cable 1979, 1983; Turner and McMullen 1982].

There have, however, been dissenting voices. One group has questioned the developmental benefits of 'dependent' industrialisation [Froebel et al 1980]. Another has tried to give intellectual flesh to the bare bones of prejudice against 'cheap labour' competition from Asia, seeking to establish that Europe in particular is seriously 'threatened' by an alien, 'supercompetitive' system of economic organisation [Hager 1982; Stoffaies 1979]. Another does not dispute the benefits that have occurred in the past but warns against extrapolating forward and, in particular, against a 'fallacy of composition' in assuming that all ldcs could follow in the footsteps of the NICs [Cline 1982]. ${ }^{2}$

The purpose of this article is twofold. The first is descriptive, to summarise roughly where the NICs now stand in world trade; the second is more ambitious, to try to advance the arguments in respect of the effect of import competition on employment, output and prices in the AICs.

\section{Recent Trends in Policy}

It is extremely difficult to monitor the overall trend in the use of protective instruments. But the attempts to

\footnotetext{
${ }^{1}$ Definitions vary but the list used by the OECD includes the following: Brazil, Mexico, Greece, Portugal, Spain, Yugoslavia, Hong Kong, Taiwan, Korea and Singapore. A wider definition would take in countries such as India, Malaysia, Thailand, the Philippines, Argentina, Colombia. A narrower one would remove the Southern European countries.
}

'For the contrasting 'optimistic' view see: [Hughes 1981]. quantify the share of 'managed trade' [Page 1980], simple enumeration of barriers and the judgements of GATT suggest the following:

First there was an upsurge in protection in the period 1976-78 which was directed substantially at NICs. This subsequently reached a plateau but may now have resumed. It needs to be remembered that overall trade policy towards the NICs and other ldcs is still heavily influenced by what happens in textiles and clothing. It can be seen from Table 1 that the level of market penetration by ldcs is significantly higher in this sector than in others and, despite the MFA restrictions was, in the 1970 s, one of the most buoyant. Since 1977 , textile restrictions have increased sharply in severity and the new generation of negotiated agreements - to run from 1982 for the EEC - is stiffer still. The severity of controls does, however, depend very much on the small print: flexibility provisions and 'safeguard' mechanisms of various kinds. It would be surprising if the growth in exports of textiles and clothing from NICs (or ldcs in general) to AICs were much to exceed 2 to 3 per cent pa in real terms in the future; far below past growth, and expectations. Current trade conflicts do, however, increasingly take place in those areas into which the more advanced NICs have moved: consumer electrics, steel and, ominously, vehicles.

Second arguments about protectionism have shifted to inter-AIC trade. Problems are both sectoral (steel, consumer electrics, cars, chemicals, farming) and across-the-board (European and US reaction to the Japanese trade surplus). It is too early to predict what will result from the protectionist sentiment in the US congress, which favours strong US measures against both the EEC and Japan. Inter-AIC competition is also taking other protectionist forms not involving imports, such as the spread of 'mixed credit' - the Aid-Trade Provision (ATP) in the UK - and the use of subsidies to 'dump' agricultural surpluses. As long as the recession continues it is difficult to see any lessening in the pressures for trade restrictions.

Third the pressure is not all in one direction. The Tokyo Round negotiations have left a legacy of modest liberalisation provisions which are now slowly

Bulletin, 1983, vol 14 no 3. Institute of Development Studies. Sussex 
Share of imports in the apparent consumption of manufactured goods in industrial countries by major product groups 1970-79

$(\%)$

\begin{tabular}{|c|c|c|c|c|c|c|c|}
\hline \multirow{3}{*}{$\begin{array}{l}\text { ISIC } \\
\text { code }\end{array}$} & \multirow{3}{*}{ product group } & \multirow{2}{*}{\multicolumn{2}{|c|}{$\begin{array}{l}\text { developing } \\
\text { country } \\
\text { imports }\end{array}$}} & \multirow[b]{2}{*}{$\begin{array}{c}\text { all } \\
\text { imports }\end{array}$} & \multirow[b]{2}{*}{$\begin{array}{l}\text { developing } \\
\text { country } \\
\text { imports }\end{array}$} & \multicolumn{2}{|c|}{$\begin{array}{l}\text { annual average } \\
\text { growth of } \\
\text { import shares }\end{array}$} \\
\hline & & & & & & $\begin{array}{c}\text { all } \\
\text { imports }\end{array}$ & $\begin{array}{l}\text { developing } \\
\text { country } \\
\text { imports }\end{array}$ \\
\hline & & \multicolumn{2}{|c|}{1970} & \multicolumn{2}{|c|}{1980} & \multicolumn{2}{|c|}{$1970-80$} \\
\hline 31 & Food, beverages and tobacco & 8.6 & 3.0 & 11.1 & 3.7 & 2.3 & 11.5 \\
\hline 32 & $\begin{array}{l}\text { Clothing, textiles and } \\
\text { leather }\end{array}$ & 11.6 & 2.7 & 25.1 & 10.5 & 7.5 & 13.1 \\
\hline 33 & Wood products & 9.5 & 1.8 & 15.6 & 3.6 & 4.9 & 7.1 \\
\hline 34 & Paper and printing & 6.6 & 0.1 & 10.2 & 0.5 & 3.1 & 11.9 \\
\hline 35 & Chemicals & 10.6 & 2.0 & 16.1 & 3.8 & 3.1 & 5.7 \\
\hline 36 & Non-metallic minerals & 5.9 & 0.3 & 9.9 & 1.1 & 4.8 & 13.8 \\
\hline 37 & Metals & 15.0 & 3.2 & 21.2 & 4.1 & 2.4 & 2.1 \\
\hline 38 & Machinery & 11.3 & 0.3 & 22.0 & 2.1 & 5.5 & 17.6 \\
\hline 3 & Manufacturing & 10.6 & 1.7 & 17.9 & 3.4 & 4.3 & 6.8 \\
\hline
\end{tabular}

Source: World Bank Import Penetration Proejct.

and quietly grinding their way to realisation: modest tariff cuts; opening up of government procurement to international tender; standards unification. The virtual failure of the November 1982 inter-ministerial meeting has, however, cast grave doubts over the extent to which GATT rules and procedures will survive. There have also been important changes in the political context. The advent of the Reagan and Thatcher governments and the loss of influence of the 'labour movement' in these and other countries have contributed to an increase in 'free trade' rhetoric. There is clearly a gap between rhetoric and practice because of the influence of business pressure groups and examples of this abound: the 'weasel words' in Reagan's Caribbean Basin initiative regarding textiles and sugar; the 'hawkish' role played by the British Government in textile negotiations, at the GATT inter-ministerial and over every import that could be classified as 'unfair'. Nevertheless, it cannot be denied that the current dominance of the political 'Right' has acted as a force against protectionism, whether directed at NICs or trade in general.

\section{Developments in the NICs}

The popular picture conjured up in the late 1970s of the NICs as a homogenous group of countries all heading for Japanese-style miracles now looks rather different. It always has been very misleading to lump together the 'city states' of Hong Kong and Singapore (themselves very different in their approach to economic management) and the much larger Korea and Taiwan. Nevertheless as a group they have dominated ldcs' exports of manufactures, and all have a record of sustained export and economic growth (see Table 2) which has held up remarkably well in the face of recession. ASEAN countries - Malaysia and Thailand especially - are beginning to show signs of a similar capacity. But there is a different picture elsewhere.

First there has been a near-collapse of Eastern European NIC at tempts to grow rapidly with Western technology imports and credit paid for by 'counter trade' exports. What will now happen to all those Polish shoes and machine tools? There is pressure from Western creditors to make the Eastern bloc export more to service its debt, but the supply problems of Eastern Europe are extremely serious. There has also been a substantial downward reappraisal of Chinese capacity as manufacturing importer and exporter (though China was able to use its market as a 'lever' in textiles negotiations with the USA). 
Second there has been a different response to post 1974 oil crises by different NICs. Some, notably Brazil and Mexico, allowed exchange rates to become overvalued in contrast to the more successful Korea and Taiwan [Balassa 1980]. The Far Eastern NICs appear more generally to have weathered the era of slower growth and protection much better than the Latin Americans. It may be, however, that the policies now being forced onto the latter group by their indebtedness problems and by the IMF will significantly raise their competitiveness in years to come.

There is also a divergence emerging between capitalist ldcs giving priority to international monetarist ideas - internal price stabilisation with exchange appreciation (the UK/Chile 'models') - and 'old-fashioned' export based growth policies using devaluation and equivalent incentives (the Korea/Japan 'model'). To put the point in another way, the contradictions between 'monetarist' and 'supply side' prescriptions are having ramifications for NIC policy. Eventually the approaches may be reconciled but the immediate effect is to widen the distance between the more successful manufacturing exporters and some possible emulators.
Third debt and payments problems have forced more and more ldcs to look to IMF and/or the World Bank for funds and they have thereby accepted greater external policy supervision. Although policy prescriptions vary both between the Bank and Fund, and between borrowers, there is evidence of influence being extended to get ldcs to adopt 'sound' trade policies, that is, neutrality between exports and import substitutes, and adjustment of exchange rates to maintain external equilibrium with fewer controls. An important example is the role of the IMF in India, where it has edged a sceptical government towards import liberalisation and export promotion. A few of the newcomers are already making an impact on world markets (Table 4). Thus, although there may be some backsliding and some NICs seem likely to drop out of the picture (mainly those in Eastern Europe) the general situation in the late 1980 s will be characterised by the existing NICs becoming more open and competitive and by more ldcs becoming NICs.

\section{The Economics of Protection and Liberalisation}

The impact of the NICs on the AICs begins to resemble a collision between an unstoppable force and

Table 2

Market penetration by region of origin

$(\%)$

\begin{tabular}{lccc}
\hline & & $\begin{array}{c}\text { share of imports of } \\
\text { manufactures to industrial } \\
\text { countries }\end{array}$ & $\begin{array}{c}\text { annual average growth } \\
\text { of the share of } \\
\text { imports }\end{array}$ \\
\cline { 2 - 4 } & 1970 & 1980 & $1970-80$ \\
\hline 1) Southern Europe & 2.0 & 3.0 & 3.2 \\
2) Far Eastern NIC exporters & 2.3 & 4.9 & 8.0 \\
3) Latin America & 5.2 & 5.2 & 0.4 \\
4) Other developing countries & 6.0 & 6.0 & 0.3 \\
5) Total developing countries (countries 1-4) & 15.5 & 19.1 & 2.4 \\
6) All industrial countries & 82.4 & 78.3 & -0.6 \\
7) Centrally-planned economies & 2.1 & 2.6 & 2.5
\end{tabular}

Note: 1) Spain, Greece, Portugal, Yugoslavia, Malta, Cyprus, Turkey, Israel

2) Hong Kong, Macau, Singapore, Taiwan, South Korea

3) includes Caribbean

4) includes China and other communist ldcs

7) Eastern Europe less Yugoslavia

Source: World Bank Import Penetration Project 


\begin{tabular}{|c|c|c|c|c|c|}
\hline $\begin{array}{c}\text { all } \\
\text { imports }\end{array}$ & $\begin{array}{l}\text { developing- } \\
\text { country } \\
\text { imports }\end{array}$ & $\begin{array}{c}\text { all } \\
\text { imports }\end{array}$ & $\begin{array}{l}\text { developing- } \\
\text { country } \\
\text { imports }\end{array}$ & $\begin{array}{c}\text { all } \\
\text { imports }\end{array}$ & $\begin{array}{c}\text { developing } \\
\text { country } \\
\text { imports }\end{array}$ \\
\hline \multicolumn{2}{|c|}{1970} & \multicolumn{2}{|c|}{1980} & \multicolumn{2}{|c|}{$1970-80$} \\
\hline
\end{tabular}

\begin{tabular}{|c|c|c|c|c|c|c|}
\hline Australia & 20.8 & 2.1 & 26.0 & 5.5 & 2.6 & 11.0 \\
\hline Canada & 26.1 & 1.2 & 31.6 & 2.1 & 1.8 & 5.1 \\
\hline European Community (of nine) ${ }^{1}$ & 18.9 & 2.7 & 32.6 & 4.6 & 4.9 & 5.7 \\
\hline Belgium & 61.7 & 5.6 & 84.6 & 6.7 & 3.4 & 2.0 \\
\hline France & 12.1 & 2.1 & 23.2 & 3.8 & 3.7 & 7.8 \\
\hline West Germany & 19.3 & 2.2 & 31.2 & 4.8 & 5.0 & 8.2 \\
\hline Italy & 15.1 & 2.1 & 31.7 & 5.2 & 6.9 & 9.4 \\
\hline Netherlands & 41.2 & 4.9 & 62.2 & 7.5 & 2.1 & 6.9 \\
\hline United Kingdom & 16.3 & 3.3 & 28.2 & 3.5 & 6.0 & -0.3 \\
\hline Japan & 4.5 & 1.3 & 6.3 & 2.5 & 2.4 & 5.8 \\
\hline Sweden & 31.0 & 2.8 & 38.0 & 3.8 & 2.5 & 3.9 \\
\hline United States & 5.4 & 1.2 & 8.7 & 2.9 & 4.6 & 8.6 \\
\hline Total of above industrial countries & 10.6 & 1.7 & 17.9 & 3.4 & 4.3 & 6.8 \\
\hline
\end{tabular}

'Excluding Greece which joined the European Community in 1981

Source: World Bank Import Penetration Project

an immovable object. The unstoppable force we have described briefly. The immovable object is represented by levels of unemployment and depressed business profits in industrial countries which are now much worse and apparently more permanent than in the late 1970s. What should the AICs do? How do the arguments for and against protection stand up in present circumstances? The conventional (but not very helpful) wisdom is that protection is both a cause and effect of unemployment: a cause because it makes for a more difficult trade-off between inflation and unemployment; an effect for obvious political reasons.

The traditional partial equilibrium analysis of costs and benefits is not really appropriate in conditions of general disequilibrium. An attempt has been made by the author and Martin Weale to use the Cambridge growth model to analyse for the UK two cases of sectoral protection of interest or potential interest to NICs (textiles/clothing; vehicles) [Cable 1982a, 1982b]. The assumptions made in the exercise are necessarily over-simplified to conform to the specifications of the model. For example it was necessary to look at the implications of restraining all imports rather than those of NICs in isolation.

We have assumed that the basic aim of the AIC government (Britain in this case) would be to prevent further import penetration in major industries. For every 1 per cent increase in income, British people choose to increase their spending on manufactured imports by somewhat more than 1 per cent. So a policy of halting market penetration would require high and rising levels of protection. We estimate on the basis of assumptions spelt out in Table 5 that in one case (clothing) the tariff equivalent of additional controls on all imports would need to be 43 per cent in 1985 increasing to 55 per cent in 1990 . For vehicles the figures are 67 per cent and 150 per cent respectively. The textiles and clothing industry figures are the lower of the two since there is already quota restraint on "low cost' imports; the tariffs and quota premia paid in the EEC on imports from the Far East often amount, already, to the equivalent of an import duty of over 50 per cent.

The model was used to compare a 'base run' forecast with one incorporating tariffs or quotas, and to analyse the difference. The analysis looks ahead to 1990 to capture some of the cumulative and 'dynamic' effects. It assumed that the government would allow the exchange rate to float, and seek to maintain a Public Sector Borrowing Requirement (PSBR) target. Hence, in the model, the exchange rate and tax rates were adjusted to maintain external (current account) 
and internal balance. In this way we tried to view the issue of import controls as seen through the eyes of present day ministers and not as part of some reflationary 'alternative strategy'.

The application of tariffs shows that what may be good for the protected industry may not be good for the economy as a whole (Tables 6, 7). For textiles, protection boosts output and employment in the industry, but in the economy at large output falls, as does personal disposable income, while there are 70,000 'lost' jobs elsewhere to set aside the industry's 'gain' of 110,000 jobs. Tariffs, by cutting imports, push up the exchange rate, so hitting the production of other traded goods and services. In the case of vehicles there are apparently more favourable results (other than a 2 per cent addition to overall consumer prices) because the import restricting effect is swamped by others. For example the import duties collected are so large as to permit a $10 \mathrm{p}$ in the $£$ cut in income tax with large consequential expenditure effects (including more spent on other imports).

In the real world large, unilateral and increasing tariffs, at least of this magnitude, are not feasible. More likely are 'voluntary export restrictions' (VERs) of the type already applied to 'low cost' textiles imports, Japanese cars, Far Eastern TVs and sundry other items. Exporters are, in effect, bribed not to export by giving them the scarcity premium which accrues from quota control. The importing country cedes a terms of trade loss in order to protect one of its industries. In the more extreme case (vehicles) this is so large as to lead to a big increase in the value of vehicle imports while the volume is cut. In general, the terms of trade loss is paid for in higher inflation and reduced personal disposable income. The effects on national employment and output seem more favourable than

Table 4

Manufactured exports of second-tier developing countries 1970-79

\begin{tabular}{|c|c|c|c|c|}
\hline & \multicolumn{2}{|c|}{$\begin{array}{l}\text { total manufactured exports } \\
\$ \text { million }\end{array}$} & \multicolumn{2}{|c|}{$\begin{array}{c}\text { manufactures as share of total exports } \\
\text { per cent }\end{array}$} \\
\hline & 1970 & 1979 & 1970 & 1979 \\
\hline Chile & 50 & 650 & 4 & 32 \\
\hline Cyprus & 5 & 227 & 5 & 50 \\
\hline Haiti & 9 & 203 & 22 & 56 \\
\hline Indonesia & 12 & 448 & 1 & $3^{2}$ \\
\hline Jordan & 11 & 157 & 32 & 39 \\
\hline Malaysia & 151 & 1,947 & 7 & $18^{2}$ \\
\hline Malta & 23 & 368 & 79 & 87 \\
\hline Mauritius ${ }^{1}$ & 1 & 101 & 1 & 27 \\
\hline Morocco & 47 & 460 & 10 & 23 \\
\hline Peru & 12 & 400 & 1 & 11 \\
\hline Philippines & 78 & 991 & 7 & 22 \\
\hline Sri Lanka ${ }^{1}$ & 5 & 132 & 2 & 25 \\
\hline Thailand & 39 & 1,213 & 5 & 23 \\
\hline Tunisia & 36 & 604 & 20 & 34 \\
\hline Uruguay & 56 & 374 & 24 & 48 \\
\hline TOTAL & 571 & 8,645 & $\begin{array}{l}7 \\
8^{2}\end{array}$ & $\begin{array}{l}17 \\
20^{2}\end{array}$ \\
\hline non NICs & 6,364 & 61,761 & $\begin{array}{l}53 \\
55^{2}\end{array}$ & $\begin{array}{l}67 \\
73^{2}\end{array}$ \\
\hline $\begin{array}{l}\text { other developing } \\
\text { countries }\end{array}$ & 4,191 & 21,637 & $\begin{array}{l}11 \\
21^{2}\end{array}$ & $\begin{array}{c}8 \\
33^{2}\end{array}$ \\
\hline
\end{tabular}

${ }^{1}$ Exports to OECD only.

${ }^{2}$ Fuel exports excluded from total exports: Indonesia 8 per cent, Malaysia 21 per cent. 


\begin{tabular}{lcc}
\hline & $\begin{array}{c}\text { before import } \\
\text { controls }\end{array}$ & $\begin{array}{c}\text { after import } \\
\text { controls }\end{array}$ \\
\cline { 2 - 3 } & $\%$ & $\%$ \\
Real annual growth of imports of vehicles (including components) & 11.5 & 4.5 \\
Real annual growth of imports of textiles and clothing & 6.1 & 1.8 \\
\hline $\begin{array}{l}\text { Tariff required to produce the restraint levels (per cent) } \\
\text { textiles } \\
\text { clothing } \\
\text { vehicles }\end{array}$ & 1985 & 1990 \\
\cline { 2 - 3 }
\end{tabular}

Table 6

Effects of import restrictions on textiles and clothing 1990

( $\%$ change from standard run unless specified)

\begin{tabular}{|c|c|c|c|c|}
\hline & tariff & $V E R s$ & $\begin{array}{c}\text { QRs given } \\
\text { to } \\
\text { companies }\end{array}$ & $\begin{array}{l}\text { tariff when } \\
\text { home prices } \\
\text { rise }\end{array}$ \\
\hline Real personal disposable income & negl. & -0.7 & -1.6 & -0.7 \\
\hline Real GDP & -0.4 & +0.2 & -2.5 & -0.9 \\
\hline Consumer prices (all) & +0.3 & +1.5 & +1.4 & +1.9 \\
\hline Employment in textiles ('000) & +110 & +125 & +78 & -34 \\
\hline $\begin{array}{l}\text { Employment in rest of UK economy } \\
\text { ('000) }\end{array}$ & -70 & +10 & -274 & -78 \\
\hline Terms of trade & +1.0 & -1.6 & +3.9 & +1.6 \\
\hline $\begin{array}{l}\text { Exchange rate to maintain external } \\
\text { balance }\end{array}$ & +2.7 & - & +9.6 & +2.7 \\
\hline $\begin{array}{l}\text { Income tax rate to maintain constant } \\
\operatorname{PSBR}^{1}(p \text { in the } \mathfrak{f})\end{array}$ & -0.3 & +0.3 & +4.4 & -0.7 \\
\hline
\end{tabular}

'Public Sector Borrowing Requirement

with tariffs except that the gains are due to the consequent devaluation which maintains external balance, and the same devaluation, on its own, gives better results.

We have assumed hitherto that, although imports are made more expensive, British producers do not respond by pushing up their prices in a more protected market to enlarge their profit margins. The same optimistic assumption underlies the advocacy of import controls by the Cambridge Economic Policy Group and is critical to the argument since a more orthodox market economy view of pricing - the "law of one price' - would indicate much stronger inflationary effects from protection. An intermediate case was investigated in which the same tariff is applied but costs and import prices are given equal weight in price formation. Export prices are also partly set with reference to home prices so there is a loss of overseas competitiveness and exports, as well as 
greater import competition. The output and employment 'gains' from tariff protection are substantially reduced in the case of cars and reversed in the case of textiles, in the latter case costing 100,000 British jobs overall.

The exercise assumed initially that workers do not act to restore real wage levels if these are affected by protection. However, a case was investigated in which workers negotiate to maintain a target real wage (Table 8). The main effects in the case considered are to make tradeable goods and services less internationally competitive, thus reducing exports, output and employment. This underlines the need for protection (like devaluation) to be accompanied by wage controls if it is to be effective.

When imports are restricted, someone, somewhere, makes a windfall profit from their relative scarcity. It could be overseas exporters in the case of VERs or the British Government (via tariffs or auctioned import quotas). Import quotas administered in Britain could be variously designed to benefit government, importers or manufacturers. Who receives the windfall gain, and how they spend it, is crucial to the economics of the exercise. A case was investigated where the windfall accrues to UK private distributors or manufacturers. The company sector saves a much higher percentage of additional income than would private consumers or government. The effects of this difference are quite dramatic. The result of a transfer from consumers to companies is that imports fall, the exchange rate appreciates and we end up with reduced prices and higher unemployment.

The conclusions so far do not depend upon the overseas exporting country maintaining some sort of balance or reciprocity in its trade relations with AICs. The UK Government appears to believe, however, that by selectively punishing those NICs which maintain high tariffs, like Brazil, it will open up these markets for British exporters. This is a bizarre theory since most of the countries concerned (Japan is in a different category) have large external payments deficits and extreme debt problems, and cannot be accused of a reluctance to import, whatever other charge is levelled at them. And some governments may take vigorous exception to any unilateral action by Britain, as several exporters to Indonesia can testify painfully. However these are judgements which cannot be quantified, as indeed neither can the wider economic costs of frustrating newly industrialising and other developing countries' efforts to break into world markets for industrial goods.

The broad conclusions are as follows. By using a national economic model it is possible to highlight the difference between sectional and national interests in the protection argument. The gain in output and employment accruing from selective protection of one industry will be offset in part or total by employment and output losses elsewhere in the economy. However, the national economic effects of sectoral protection vary as between industries and according to the

Table 7

Effects of import restrictions on vehicles

( $\%$ change unless specified)

\begin{tabular}{|c|c|c|c|c|}
\hline & tariff & $V E R s$ & $\begin{array}{l}\text { tariff when } \\
\text { home prices rise }\end{array}$ & $\begin{array}{l}\text { QRs given to } \\
\text { companies }\end{array}$ \\
\hline Real personal disposable income & +4.2 & +1.2 & +2.6 & -1.6 \\
\hline Real GDP & +2.5 & +5.4 & +0.7 & -3.8 \\
\hline Consumer prices & +1.9 & +6.0 & +3.7 & -4.1 \\
\hline Employment in vehicles ('000) & +100 & +116 & +11 & +65 \\
\hline $\begin{array}{l}\text { Employment in rest of UK economy } \\
\left({ }^{\prime} 000\right)\end{array}$ & +343 & +716 & +174 & -400 \\
\hline Terms of trade & -0.4 & -10.6 & -0.7 & +7.7 \\
\hline $\begin{array}{l}\text { Exchange rate to maintain external } \\
\text { balance }\end{array}$ & -1.3 & -13.0 & +1.3 & +20.8 \\
\hline $\begin{array}{l}\text { Income tax rate to maintain constant } \\
\operatorname{PSBR}^{1}(p \text { in the } \mathfrak{f})\end{array}$ & -11.0 & -6.0 & -11.0 & +6.5 \\
\hline
\end{tabular}

\footnotetext{
${ }^{1}$ Public Sector Borrowing Requirement
} 
techniques of protection used. In terms of the effects on real personal disposable income, greater protection of textiles and clothing has little to commend it on any assumption, and even the claim that it saves jobs is dubious. By contrast the motor vehicles industry gives more favourable results though these depend precariously on the assumptions made about pricing, wage behaviour and the use of quota premia. Bearing in mind the major qualifications made, the policy implication is that, faced with the unstoppable force, the immovable object should certainly try to move; that is, it should adjust to its trading comparative advantage.

\section{Where do we go next?}

While the issue of protection and trade liberalisation can be confronted academically in terms of overall costs and benefits, policy formation is institutionally bound and reflects preoccupations which do not have a strong economic rationale such as 'reciprocity', 'fairness' and geopolitical interests. The following is a brief summary of where we now stand on negotiating issues of critical importance to NICs and ldcs in general.

i) The textiles Multi-fibre Agreement (MFA) has been renewed until 1987 and bilateral agreements within it are largely complete. The extension, like previous extensions, has been rationalised in terms of short run political and social considerations. But what is the long term future of the textile and clothing industries in AICs? The revised MFA is more explicit than its predecessors about the need for 'adjustment', but this may be just rhetoric.

ii) Tariffs are not an entirely dormant issue; Tokyo Round signatories will have to approve the second stage of cuts to run from 1984/85. Ldcs continue, through UNCTAD, to invest hopes in the GSP (tariff preferences) despite all the evidence that this is largely an unimportant side-show.

iii) The US made a major issue of services liberalisation at the GATT inter-ministerial meeting but so far little progress has been made. There are interesting and unfamiliar problems such as access to 'telematics'; banking regulations; and the link between trade and investment, as in tourism and insurance. Ldcs have an opportunity in the long term to develop services exports, but have so far adopted a negative approach to negotiations, fearing for their 'infant' industries in insurance and banking, and suspecting that freer trade in services is a first step to looser controls on MNCs.

iv) Safeguards for manufacturers: this issue has remained unresolved since the Tokyo Round. The argument is over whether the EEC is willing to give up some freedom to demand negotiated quota restraints in return for some acceptance by NICs/Japan that 'selective' import quota measures can be taken (ie against them on a discriminatory basis). GATT is eager to introduce some order and discipline in this area, with a more realistic code of conduct for safeguard action. But the EEC prefers its present freedom to use VERs or unilaterally imposed quotas as a means of dealing with the 'threat' from NICs in particular products.

v) 'Graduation' procedures: UNCTAD seems to be digging in its heels against 'graduation' by NICs; that is, against moves towards greater 'reciprocity' and away from a strict interpretation of 'special and differential' treatment for ldcs. However, reciprocity is occurring anyway and it is simply no longer a sustainable position that Korea and Brazil should be treated on the same basis as Sri Lanka or Kenya. NIC governments (especially Korea and Brazil) have to

Table 8

Effects of treating wages endogenously: textile tariffs

(difference from exogenous wage case)

(\% change unless stated)

Real PDI

Real GDP

Employment ('000)

Prices

Terms of Trade

Exchange Rate ${ }^{1}$

Economic Tax Rate ( $p$ in the $\mathfrak{E})^{1}$

Balance of payments ( $£$ bn at constant 1975 prices) ${ }^{1}$

PSBR $(\mathfrak{f} \text { bn })^{1}$

$$
\begin{gathered}
\text { negl } \\
-0.7 \\
-206 \\
+2.3 \\
+1.0 \\
- \\
+0.7 \\
-3.5 \\
+8
\end{gathered}
$$

\footnotetext{
${ }^{1}$ In this case we did not attempt to bring about external and internal balance.
} 
consider what advantages they will get by calling the bluff of Western business and governments, who complain about their high trade barriers, and offering reciprocal liberalisation. Some NICs are liberalising unilaterally but the complainants seem not to have noticed, or to be giving them credit for it. The balance of payments of some NICs, eg Brazil and Mexico are a more immediate constraint.

vi) Japan: the NICs are indirectly affected by the trade conflict between Japan and the EEC and US. A spread of product restrictions on Japanese exports will probably create precedents for restrictions on the NICs (eg consumer electronics) to the extent that one is needed. On the other hand, if Japan can be persuaded to use its balance of payments surplus to pursue some expansionary policies and open up its home market (or even give more aid) then NICs (and other Idcs) may be helped.

\section{Global Talks}

It is possible that after the inconclusive GATT interministerial meeting a new round of international negotiations on trade liberalisation could be launched to resolve outstanding problems on inter AIC trade such as agriculture, to further the hesitant progress made on non-tariff codes, and to look afresh at the ldc and NIC issues which were overlooked, or by-passed, in the Tokyo Round. Given the high ideological profile accorded to 'free trade' by the main Western governments, global negotiations on liberalisation might seem propitious; but as the GATT talks demonstrated, negative political pressures on them are also great. There is little sign that the EEC, in particular, is interested in anything more ambitious than achieving a (low) lowest common denominator of its 10 national interests. The US administration is fighting a rear-guard action against protectionists in Congress, and is trying to head off damaging conflict with the EEC, and with Japan. In these circumstances, the prospects of NICs and other ldcs being given sympathetic consideration in global negotiations are remote.

Is there the prospect of regional initiatives? There is already a degree of implicit regionalism in trade and in trade policy. The attempt of the EEC to assimilate Mediterranean NICs through accession or association is one example, as are US sensitivity to Mexican/Caribbean interests, and Japanese involvement in Pacific basin NICs. A failure to resolve issues globally may lead to greater emphasis on this approach. And the EEC might, realistically, be expected to cope better with the centre-periphery problem of freer trade with Mediterranean NICs rather than with NICs as a whole. But the philosophy is fundamentally anachronistic: trade no longer flows in neat geopolitical, let alone colonial, channels; communications and transport cost reductions have eliminated most of the advantages of proximity.

\section{Signs of Hope?}

In current circumstances it is easy to counsel pessimism in trade policy. An extrapolation into the 1980 s of the manufacturing export growth rates achieved by ldcs in the 1960s would certainly lead rapidly to disillusionment, and to a good deal of excess capacity in Idc export industries. There is, however, a danger of over-reaction; of coming to regard 'protectionism' as an impossible barrier rather than, as it is, a patchy network of partial controls. Statistical evidence, at least up to the recent past, shows that the NICs continue to grow relatively rapidly, that ldcs diversifying into manufactured exports are achieving substantial growth in these items, and that AICs are continuing to cede market penetration. Several poor countries (some members of the ASEAN group and China) have shown a willingness to retaliate against trade restrictions and achieve concessions thereby. There are important interest groups in AICs resisting the pressures of protectionism. The immovable object not only ought to move; it probably will, slowly.

\section{References}

Balassa, B., 1980, 'The newly industrialising countries after the oil crisis', Staff Working Paper no 437, World Bank, Washington

Cable, Vincent, 1979, 'Britain, the new protectionism and ldc imports', International Affairs, vol 55 no 1

-1983, Protection and Industrial Decline, Hodder \& Stoughton, London

-and M. Weale, 1982a, 'The economics of import controls', ODI, London, mimeo

-and M. Weale, 1982b, 'British aid and trade policy, use of the Cambridge growth model', ODI Review 1

Cline, W. R., 1982, 'Can the East Asian model of development be generalised?', World Development, vol 10 no 2

FCO, 1979, The Newly Industrialising Countries and the Adjustment Problem, London

Froebel, F., J. Heinrichs and O. Keye, 1980, The New International Divisions of Labour, Cambridge University Press

Hager, W., 1982, 'Protectionism and autonomy: how to preserve free trade in Europe', International Affairs, summer

Hughes, H. and J. Waelbroeck, 1981, 'Can the growth of developing country exports continue in the 1980s', World Economy, vol 4 no 2 
OECD, 1979, The Impact of Newly Industrialising Countries, Paris

Page, S., 1980, 'The increased use of trade controls by the industrialised countries', Intereconomics no 3
Stoffaies, C., 1979, La Grande Menace Industrielle, CalmannLévy, Paris

Turner, L. and N. McMullen, 1982, The Newly Industrialising Countries: Trade and Adjustment, Allen and Unwin 